\title{
MOLECULAR MARKER AIDED BREEDING FOR BLAST RESISTANT RICE IN NEPAL
}

\author{
Bal K. Joshi ${ }^{1}$, Hari P. Bimb ${ }^{1}$, Gopal Parajuli ${ }^{2}$ and Bedanand Chaudhary ${ }^{3}$
}

\section{ABSTRACT}

Molecular markers tightly linked to target gene have been identified in different chromosomes to impose the genetic selection. This paper summarizes the progress and achievement made in breeding for blast resistance rice based on DNA markers. At least 40 genes conferring resistance to blast isolates with multiple alleles have been described. Both dominant and recessive resistance alleles have been found in many rice landraces. Highly polymorphic and easily detectable SSR markers are being used in breeding for blast resistance. Bulked segregant analysis (BSA) is the simple method for tagging resistance gene by SSR markers. Quantitative trait loci (QTLS) have also been mapped and most of them are linked to qualitative genes. Simple sequence repeat (SSR) markers linked to the gene are being used to select plants possessing the desired trait and markers throughout the genome are being used to select plants that are genetically similar to recurrent parent. Using SSR markers it may be possible to select blast resistance genotypes at any stage of crop development from any small part of crop, to conduct many round of selection, to select without inoculums, without scoring, and without testing in hot spot or artificial inoculation. Molecular based blast resistance breeding work is necessary to initiate in Nepal focusing on resistance gene tagging in Nepalese rice landraces and utilization.

Key words: Blast resistance, DNA marker, gene tagging, rice

\section{INTRODUCTION}

Rice (Oryza sativa L.) is the most preferred crop of Nepalese farmers and they are growing about 2000 different rice landraces and 67 improved rice cultivars from 60 $\mathrm{m}$ to $3050 \mathrm{~m}$ altitude (Upadhyay and Joshi, 2003). In all rice growing areas blast disease caused by (Magnaporthe grisea (Herbert) Borr. (anamorph Pyricularia oryza Cav. $=P$. grisea (av.) is the most serious fungal disease causing heavy yield losses from 10 to $80 \%$ (Manandhar et al., 1992). The fungus produces spots or lesions on leaves, nodes and different parts of panicles and grains. The neck blast makes more significant yield and quality losses than leaf blast (Katsube et al., 1970). While highly positive correlation between resistance to leaf and neck blast has been generally observed, inconsistency between resistance to leaf and neck blast was also evident (Zhuang et al., 2002).

Blast disease is the most destructive disease worldwide. Growing resistant varieties has been the most effective and economic way to control the disease but resistance is often lost in a few years after cultivars released because of the high variability of the rice blast fungus. To breed rice varieties with more durable blast resistance,

\footnotetext{
${ }_{1}^{1}$ Genebank-NARC, PO Box 3055, Kathmandu, Nepal, joshibalak@yahoo.com

2 Plant Pathology Division-NARC, Khumaltar, Kathmandu

${ }^{3}$ RARS-NARC, Tarahara, Siraha
} 
multiple resistance genes utilizing both qualitative and quantitative genes must be incorporated into individual varieties. This necessitates the exploration of more efficient selection and breeding strategies than those currently exist. Recent advancements in DNA marker technology may provide new solutions for selecting and maintaining more durable resistance genotypes in rice. In contrast to the traditional selection based on phenotypic screening, molecular markers are refractory to environmental variation. Upon identification of molecular markers closely linked to desirable trait/s, marker assisted selection (MAS) can be performed for multiple resistance in early segregating generations and at early stages of plant development. This paper summarize the progress and achievement made in breeding for blast resistance based on DNA markers which will help in planning blast resistance gene tagging in Nepalese rice genotypes and developing blast resistant inbred line or near isogenic line (NIL).

\section{GENETICS OF BLAST RESISTANCE IN RICE}

The genetics of rice blast have been extensively studied and two types of resistance have been described, complete (true or vertical) and field resistance (horizontal) (Fukuoka and Okuno, 2001). Rice blast is one of the best characterized models for understanding molecular mechanisms of natural defense response. Resistance to infection by this fungus follows a classic gene for gene theory (Silue et al., 1992). The Pi-b and Pi-ta genes are two major blast resistance (R) genes that have been characterized molecularly (Wang et al., 1999). Genetic analysis of blast resistance studied by several researchers indicated either monogenic dominant, monogenic recessive, two dominant independent genes, two dominant complementary genes and two recessive duplicate genes or resistance controlled by minor genes. Mostly the genes resistance to blast fungus is monogenic dominant. Multiple alleles upto 5 are identified (Imbe et al., 2000; Hittalmani et al., 1995). Mackill and Bonman (1992) developed 22 near isogenic lines (NILs) each having a single complete R gene from $\mathrm{CO} 39$ to study the genetics of blast resistance. At least four independent loci, $\mathrm{Pi}-1$ to $\mathrm{Pi}-4$ were identified after inheritance study using these NILs. Inukai et al. (1994) showed that Pi-1 was allelic to Pi-z. Structural and functional analyses of many major $\mathrm{R}$ genes have shown that they encode proteins with similar structural motifs- nucleotide binding site, kinase domains, leucine-rich repeats- that are responsible for ligand recognition and signal transduction (Wu et al., 2004). Most studies have suggested that field resistance to blast is under complex genetic control and multiple genes are responsible for the expression of field resistance (Higashi and Saito, 1985).

\section{QUALITATIVE AND QUANTITATIVE GENES FOR BLAST RESISTANCE}

True resistance is governed by qualitative gene also called major gene and field resistance by quantitative genes called minor genes. More than 40 qualitative resistance genes for blast fungus have been identified (Annex 1). Most of them are dominant and located in chromosome 6,11 and 12. In some loci multiple resistance alleles are identified. The wide genetic variation available in blast fungus may be the main factor to evolve many resistance genes in rice. These two resistance types, complete and field resistance are under monogenic and polygenic systems respectively. Pi-k has 5 alleles, Pi-2 locus has 2 and Pi-ta has 2 alleles (Bryan et al., 2000; Fjellstorm et al., 2006; Hittalmani et al., 1995). Four $R$ genes have been 
identified in Tetep and $3 \mathrm{R}$ genes in Pai-Kan-Tai. Wang et al. (1994) has described 10 QTLs, of which two QTLs are located in chromosome 4. Fukuoka and Okuno (2001), Liu et al. (2004) had also detected QTLs. Majority of the QTLs are associated with qualitative genes.

\section{ALLELES MINING AND MOLECULAR TAGGING}

Rice genome is completely sequenced and it is available publicly (www.ncbi.nlm.nih.gov). This helps to discover the genes in rice and other related plant species. Discovery of genes controlling economically important traits can be used for application in MAS and discovery of new beneficial alleles in the germplasm (allele mining). Rice genome has 430 million bp (about 1/10 of human) with estimated 50,000 genes (Fjellstrom et al., 2006). This publicly available DNA sequences have been used to scan for SSR region and to design primers. Fjellstrom et al. (2006) developed markers closely linked to Pi-z locus from the analysis of publicly available genome sequence of Nipponbare rice variety.

Molecular mapping and tagging of agronomically important traits are prerequisites for MAS and marker assisted backcrossing (MAB). Different methods are available to tag the genes by DNA markers. These include bulked segregant analysis (BSA), preselection using NILs, preparative pulsed field gel electrophoresis and chromosome walking and jumping. BSA provides a rapid, technically simple alternative for identifying markers linked to specific genes. The only prerequisite is the existence of a population resulting from a cross that segregates for the gene of interest (Michelmore et al., 1991). The success of the approach will depend on the genetic divergence between the parents in the target region.

\section{MARKERS LINKED TO BLAST RESISTANCE GENES AND MOLECULAR SCREENING}

Dense linkage map of rice is available for restriction fragment length polymorphism (RFLP) and SSR markers. More than 15 RFLP markers tightly linked to blast R genes are identified. Due to some limitation of RFLP markers for examples complex laboratory procedure, research is moving forward in SSR and single nucleotide polymorphism (SNP) markers. About 10 SSR markers closely linked to blast R genes are available. Upon the identification of DNA markers, screening of large germplasm can be done at any time and any growth stages. In case of screening the disease resistance, genotypes can be screened at early stage of segregating generation without inoculating and scoring. For phenotypic screening, genes must be expressed. SSR markers due to very large in number are considered very useful in screening program.

\section{MOLECULAR AIDED BREEDING}

Breeding work utilizing both phenotypic and genotypic markers are more reliable and fast. Conventional breeding are based on gene expression however there are many limitations, For example epistatic effect is the one. Molecular breeding on the other hand has an opportunity to monitor and manipulate traits without gene expression. MAS and $M A B$ are the two major approaches to accelerate breeding works. Molecular approach is more suitable to pyramid genes and to dissect the 
complex traits such as grain yield, plant height, etc. Hittalmani et al. (2000) developed three genes pyramid rice using MAS. These genes are Pi-1, Piz-5 and Pita. Three varieties, CO39, A57-115-8 and Moroberekan are 3 genes pyramid varieties resistance to blast fungus. Combination of $\mathrm{Pi}-18, \mathrm{Pi}-21$ and $\mathrm{Pi}-22 \mathrm{Pr} \mathrm{Pi}-1$ and Piz-5 in a variety is reported effective for durable resistance. Main advantages of molecular breeding are selection at any stage of crop development, at early segregating generation, many round of selection, selection without gene expression. In addition to this, only small part is enough for screening multiple characters.

\section{LEAF AND NECK BLAST RESISTANCE}

Neck blast is the major problem in Nepal and yield loss from this is reported higher than leaf blast. Relatively other methods for controlling this disease are available for leaf blast fungus and research is more focused on leaf blast. Positive correlation between leaf and neck blast resistance is observed but inconsistent also exist. Site specific donor for leaf and neck blast resistance should be identified and their genetics should be studied in local germplasm. Neck blast is a major problem in many countries. Pi-k in chromosome 11 has been reported effective against neck blast. However, there is reported a cluster of genes in this region. If the gene functions at all growth stages, the gene would be useful, but not all genes function to be effective at all stages, thus, it is possible that resistance at seedling or leaf blast stage may not be useful for neck blast.

\section{BREEDING FOR BLAST RESISTANCE IN NEPAL}

Every year NARC screen more than 1000 rice genotypes using conventional breeding approach and more than $50 \%$ are found resistance to blast fungus. Most of the screening materials are breeding lineinsertes generated from national breeders and line received from IRRI. Every year international materials are tested in Nepal and IRRI summarized the results (Table 1). Internationally resistance lines are the good sources of resistance genes. Screening sites are mainly Khumaltar (located in the mid hill), Hardinath (located in Tarai), and Lumle (located in mid hill). Hot spots where pathologists and breeders screen the germplasm for blast disease are Bijayanagar-Jumla, Gokarna-Lalitpur, Chaling-Lalitpur, Dharmasthali-Kathmandu, Kavrasthali-Kathmandu, Bhawasi-Mahottary and Bharatpur-Dhanusha. BhawasiMahottary is the hot pocket for neck blast screening. A number of rice genotypes have been identified (list of genotypes not shown) either resistance or susceptible to blast fungus in different locations (Adhikari and Shrestha, 1986; Chaudhary and San, 1997; Chaudhary and Sah, 1998; Chaudhary et al., 1994; Chaudhary, 1995; Manandhar et al., 1992; Manandhar, 1984; Manandhar, 1987). Regarding blast pathogenic races, 15 pathotypes are reported to date (Chaudhary et al., 2005). It may increase if more isolates are tested. There are many local as well introduced genotypes that are resistant and susceptible to blast in Nepal (Thapa and Manadhar, 1985; Pradhanang, 1988; Chaudhary, 1995; Manandhar et al., 1992; Manandhar, 1984; Manandhar, 1987). However, Laxmi, Sabitri, Janaki, Radha-12, Khumal-11 are some rice varieties found resistant to blast. Laxmi is resistant to the most virulent isolate ever tested (that isolate can produce disease on rice genotype with 3 genepyramid). Therefore, Laxmi may be the nationally resistance variety. Masuli or 
Sankharika may be nationally susceptible genotypes and CO39 or LTH are international susceptible lines. Tetep may be considered universally resistance genotype (Chaudhary, 1995; Manandhar et al., 1992).

Resistance is often lost in a few years after cultivars being released and undergone mass cultivation. For example Khumal-4 is a fine variety. It is in general observed in plants that interaction between resistant varieties and locations are found significant. Similarly interactions between resistant varieties and years have also been found significant.

Table 1. Best varieties for resistance against blast disease screened in International Network for Genetic Evaluation of Rice (INGER) nurseries during 1975-1995

\begin{tabular}{lll}
\hline SN & Variety & Origin \\
\hline 1. & Carreib, Takudan & Philippines \\
2. & CIATICA-5 & Colombia \\
3. & $\begin{array}{l}\text { IR1905-81-3-1, IR1416-128-5-8, IR2793-80-1, IR116-1-42-2-3-3, IR1905-PP11- } \\
\text { 29-4-61, IR457-6-3-2, IR5533-PP850-1, IR32429-47-3-2-2, WHD-IS-75-1, }\end{array}$ \\
& $\begin{array}{l}\text { IR59606-119-3 } \\
\text { 4. }\end{array}$ IRAT13 & Cote d'lvoire \\
5. & IRAT144 & Burkino Faso \\
6. & IRI387 & Korea \\
7. & MG3 & China \\
8. & Ta-poo-cho-z, Huan-sen-goo & Taiwan \\
9. & Tetep & Vietnam \\
10. & Tres Naruas & Brazil \\
\hline
\end{tabular}

Source: Chaudhary, 1996

\section{DONORS OF RESISTANCE GENE TO NEPALESE CULTIVARS}

Pedigree analysis of Nepalese rice cultivars indicates that 14 ancestors of these cultivars are resistance to blast fungus (Table 2). The ancestor, Sigadis was used in 13 cultivars. These ancestors may not be resistance to all race of blast fungus in Nepal. Suitable resistance gene donor for particular area should be identified so that breeder can use them as parent in hybridization program.

\section{BREEDING APPROACH FOR BLAST FUNGUS MANAGEMENT}

Breeding the resistant variety is considered best way for controlling the disease. For that both qualitative and quantitative genes should be utilized. Cultivars mixture, multilines, near isogenic lines or resistance inbred lines are reported effective approaches for disease management. It is also suggested that crop rotation can help to reduce the disease intensity. Gene and individual QTL pyramiding should be considered for durable resistance to blast fungus. 
Table 2. Ancestors of 48 improved rice cultivars released in Nepal (1965-2002) and their reaction to blast fungus

\begin{tabular}{|c|c|c|c|c|c|}
\hline SN & Ancestor & Origin & Group & $\begin{array}{l}\text { Reaction to blast } \\
\text { fungus }\end{array}$ & $\begin{array}{l}\text { Contributed } \\
\text { cultivars, } \mathrm{n}\end{array}$ \\
\hline 1. & AKIYUDAKA & Korea & Japonica & Resistance & 1 \\
\hline 2. & ANNAPURNA & $?$ & $?$ & Susceptible & 1 \\
\hline 3. & B531B-TK39 & $?$ & $?$ & - & 1 \\
\hline 4. & BPI 76 & Philippines & Indica & Susceptible & 1 \\
\hline 5. & C4-63-GB & $?$ & $?$ & - & 1 \\
\hline 6. & CENTURY PATNA & USA & Indica & Susceptible & 13 \\
\hline 7. & CHINA 1039 & India & Indica & Susceptible & 1 \\
\hline 8. & CHINA 971 & China & $?$ & - & 1 \\
\hline 9. & CHINA-1039-DWF-MUT & China & Indica & Susceptible & 1 \\
\hline 10. & CHINA-45 & China & $?$ & Susceptible & 1 \\
\hline 11. & CINA & China & $?$ & - & 28 \\
\hline 12. & $\mathrm{CO}-18$ & India & Indica & Susceptible & 15 \\
\hline 13. & $\mathrm{CO}-29$ & India & Indica & Susceptible & 1 \\
\hline 14. & DEE GEO WOO GEN & Taiwan & Indica & Susceptible & 23 \\
\hline 15. & DUNGHAN SHALIL & $?$ & INDICA & Susceptible & 1 \\
\hline 16. & FUJI-102 & Japan & Japonica & Resistance & 2 \\
\hline 17. & GEB 24 & India & Indica & Susceptible & 15 \\
\hline 18. & GHANDRUK LOCAL & Nepal & Japonica & Resistance & 2 \\
\hline 19. & GP-15 & $?$ & $?$ & - & 8 \\
\hline 20. & $\mathrm{H} 4$ & Ceylon & Indica & Resistance & 1 \\
\hline 21. & H501 & Ceylon & Indica & Resistance & 3 \\
\hline 22. & HR 21 & India & Indica & Susceptible & 1 \\
\hline 23. & HSINCHU-4 & Taiwan & Japonica & Susceptible & 1 \\
\hline 24. & JARNELI & Nepal & Indica & - & 1 \\
\hline 25. & JERAK & $?$ & $?$ & - & 4 \\
\hline 26. & JINLILNG-78-102 & China & Japonica & - & 1 \\
\hline 27. & JUMLI MARSHI & Nepal & Japonica & Susceptible & 1 \\
\hline 28. & K-28-76-B-1 & India & Japonica & - & 1 \\
\hline 29. & $\mathrm{KN}-1 \mathrm{~B}-214-1-4-3$ & Indonesia & Indica & - & 1 \\
\hline 30. & KULU & Australia & Indica & - & 1 \\
\hline 31. & LALNAKANDA & India & Indica & Susceptible & 1 \\
\hline 32. & LATISAIL & Pakistan & Indica & Susceptible & 28 \\
\hline 33. & LD-66 & $?$ & $?$ & - & 1 \\
\hline 34. & MAS & Indonesia & Indica & Susceptible & 3 \\
\hline 35. & MAYANG EBOS-80 & Malaysia & Indica & Resistance & 3 \\
\hline 36. & MCVA & $?$ & $?$ & - & 1 \\
\hline 37. & MTU15 & India & Indica & Susceptible & 1 \\
\hline 38. & MUDGO & India & Indica & Susceptible & 1 \\
\hline 39. & MUTANT-65 & $?$ & $?$ & - & 1 \\
\hline 40. & O. NIVARA & $?$ & $?$ & - & 11 \\
\hline 41. & OB678 & Srilanka & $?$ & - & 1 \\
\hline 42. & O-LUAMCHU & $?$ & $?$ & - & 1 \\
\hline 43. & POKHRELI MASINO & Nepal & Indica & Susceptible & 3 \\
\hline 44. & $\mathrm{PP}$ & $?$ & $?$ & - & 3 \\
\hline
\end{tabular}




\begin{tabular}{|c|c|c|c|c|c|}
\hline SN & Ancestor & Origin & Group & $\begin{array}{l}\text { Reaction to blast } \\
\text { fungus }\end{array}$ & $\begin{array}{l}\text { Contributed } \\
\text { cultivars, } \mathrm{n}\end{array}$ \\
\hline 45. & PTB 18 & India & Indica & Resistance & 5 \\
\hline 46. & РTB 21 & India & Indica & Resistance & 5 \\
\hline 47. & R. HEENATI & $?$ & $?$ & - & 1 \\
\hline 48. & REMADJA & Indonesia & Indica & Resistance & 3 \\
\hline 49. & $\mathrm{RP72}$ & India & Indica & - & 1 \\
\hline 50. & SHANKARA & Nepal & Indica & - & 1 \\
\hline 51. & SHINEI & Japan & $?$ & Susceptible & 1 \\
\hline 52. & SHINIRI AIKOKU & $?$ & $?$ & - & 1 \\
\hline 53. & SIGADIS & Indonesia & Indica & Resistance & 13 \\
\hline 54. & SLO & India & Indica & Susceptible & 13 \\
\hline 55. & T141 & India & Indica & Susceptible & 3 \\
\hline 56. & TADUKAN & Philippines & Indica & Resistance & 11 \\
\hline 57. & TAICHUNG NATIVE1 & Taiwan & Indica & Susceptible & 22 \\
\hline 58. & TAICHUNG-150 & Taiwan & Japonica & Resistance & 1 \\
\hline 59. & TAICHUNG-45 & Taiwan & Japonica & - & 1 \\
\hline 60. & TAICHUNG-65 & Taiwan & Japonica & Resistance & 4 \\
\hline 61. & TAIPEI-7 & Taiwan & $?$ & - & 1 \\
\hline 62. & TCA-80-4 & India & Indica & - & 1 \\
\hline 63. & TETEP & Vietnam & $?$ & Resistance & 2 \\
\hline 64. & TSAI YUAN CHUNG & Taiwan & Indica & Susceptible & 2 \\
\hline 65. & WAIKAKKU & $?$ & $?$ & - & 1 \\
\hline 66. & YUNLEN-1 & China & Japonica & Susceptible & 1 \\
\hline
\end{tabular}

? Not known. Source: Joshi, 2004; Joshi, 2005.

\section{WAY FORWARD}

For effective management of blast disease, breeding work should be focused on utilizing the broad spectrum of resistance genes (Pi-2, Pi-9 (t), Pi-5 (t), Pi-z, Piz-5) and pyramiding genes and QTLs. Positive correlation between leaf and neck blast resistance are reported but, this is not applicable in all cases. Breeding for neck blast resistance is therefore necessary in Nepal. Introduction of exotic genes for resistance induced the occurrence of new races of blast fungus, therefore breeding work should be concentrated in local resistance genes using molecular markers. Mapping of resistance genes in rice landraces are necessary to speed up the marker assisted blast resistance rice breeding in Nepal. DNA sequences of rice can be considered to design the primers linked to blast resistance.

\section{REFERENCES}

Adhikari, T.B. and S.M. Shrestha, 1986. Blast epidemic in Chitwan valley, Nepal. International Rice Research Newsletter, 11(2):22.

Ahn, S.N., Y.K. Kim, H.C. Hong, S.S. Han, S.J. Kwon, H.C. Choi, H.P. Moon and S.R. McCouch, 2000. Molecular mapping of a new gene for resistance to rice blast (Pyricularia grisea Sacc). Euphytica, 116:17-22.

Berruyer, R., H. Adreit, J. Milazzo, S. Gaillard, A. Berger, W. Dioh, M.H. Lebrun and D. Tharreau, 2003. Identification and gene mapping of Pi33, the rice resistance gene 
corresponding to the Magnaporthe grisea avirulence gene ACE1. Theor. Appl. Genet., 107:1139-1147.

Bonman, J.M. and D.J. Mackill, 1988. Durable resistance to rice blast. Oryza, 25:103-110.

Bonman, J.M., G.S. Khush and R.J. Nelson, 1992. Breeding rice for resistance to pests. Ann. Rev. Phytopathology, 30:507-528.

Bonman, J.M., 1992. Durable resistance to rice blast - environmental influences. Euphytica, 63:115-123.

Bryan, G.T., K.S. Wu, L. Farrall, Y.L. Jia, H.P. Hershey, S.A. McAdams, K.N. Faulk, G.K. Donaldson, R. Tarchini and B. Valent, 2000. A single amino acid difference distinguishes resistant and susceptible alleles of the rice blast resistance gene Pi-ta. Plant Cell, 12:2033-2045.

Chaudhary, B. and D.N. Sah, 1997. Effect of promising rice genotypes on leaf blast disease progression. Nepal Agriculture Research Journal, 1:27-31.

Chaudhary, B. and D.N. Sah, 1998. Efficacy of Beam 75 WP in controlling leaf blast disease at the seedling stage of rice. Nepal Agriculture Research Journal, 2:42-47.

Chaudhary, B., M. Yadav, R.N. Chaudhary and D.N. Sah, 2003. Resistance in rice genotypes to blast. In: Proc. 23rd National Summer Crops Research Workshop, 2-4 July 2002, Kathmandu, pp.262-280.

Chaudhary, B., P.B. Karki and K.K. Lal, 1994. Neck blast resistant lines of Radha-17 isolated. International Rice Research Notes, 19(1):11.

Chaudhary, B., S.M. Shrestha and R.C. Sharma, 2005. Resistance in rice breeding lines to the blast fungus in Nepal. Nepal Agriculture Research Journal, 6:49-56.

Chaudhary, B., 1995. Selection of Masuli-isoline resistant to blast disease. Paper presented in The 18thSummer Crops Workshop held at National Maize Research Program, Rampur, Nepal.

Chaudhary, B., 1999. Effect of blast disease on rice yield. Nepal Agriculture Research Journal, 3:8-13.

Chaudhary, R.C., 1996. Internationalization of elite germplasm for farmers: Collaborative mechanisms to enhance evaluation of rice genetic resources. In: The Fourth Ministry of Agriculture, Forestry and Fisheries, Japan International Workshop on Genetic Resources, 22-24 October 1996. pp. 221-243.

Chauhan, S., M.L. Farman, H.B. Zhang and A. Leong, 2002. Genetic and physical mapping of a rice blast resistance locus, PiCO39(t), that corresponds to the avirulence gene AVR1CO39 of Magnaporthe grisea. Mol Genet Genomics, 267:603-612.

Chen, D.H., M. dela Vina, T. Inukai, D.J. Mackill, P.C. Ronald and R.J. Nelson, 1999. Molecular mapping of the rice blast resistance gene, Pi44(t), in a line derived from a durably resistant rice cultivar. Theor. Appl. Gennet., 98:1046-1053.

Chen, D.H., R.S. Zeigler and S.W. Ahn, 1996. Phenotypic characterization of the rice blast resistance gene $\mathrm{Pi}-2(\mathrm{t})$. Plant Disease, 80:52-56.

Fjellstorm, R., A.M. McClung and A.R. Shank, 2006. SSR markers closely linked to the Pi-z locus are useful for selection of blast resistance in a broad array of rice germplasm. Mol. Breed., 17:149-157.

Fujii, K., Y. Hayano-Saito, K. Saito, N. Sugiura, N. Hayashi, T. Tsuji, T. Izawa and M. Iwasaki, 2000. Identification of a RFLP marker tightly linked to the panicle blast resistance gene, $\mathrm{Pb} 1$, in rice. Breed. Sci., 50:183-188.

Fukuoka, S. and K. Okuno, 2001. QTL analysis and mapping of pi21, a recessive gene for field resistance to rice blast in Japanese upland rice. Theor. Appl. Genet., 103:185-190.

Higashi, T. and S. Saito, 1985. Linkage group of field resistance genes upland rice variety Sensho to leaf blast caused by Pyricularia oryzae Cav. Japan J Breed., 35:438-448.

Hittalmani, S., M.R. Foolad, T. Mew, R.L. Rodriguez and N. Huang, 1995. Development of a PCR based marker to identify rice blast resistance gene, $\mathrm{Pi}-2(\mathrm{t})$ in a segregating population. Theor. Appl. Genet., 91:9-14.

Imbe, T., H. Tsunematsu, H. Kato and G.S. Khush, 2000. Genetic analysis of blast resistance in IR varieties and resistant breeding strategy. In:D. Tharreau, M.H. Lebrun, N.J. Talbot 
and J.L. Notteghem (eds.). Advances in Rice Blast Research. Kluwer Academic Publishers, CAB International, pp.1-8.

Inukai, T., R.J. Nelson, R.S. Zeigler, S. Sarkarung, D.J. Mackill, J.M. Bonman, I. Takamure and T. Kinoshita, 1994. Allelism of blast resistance genes in near isogenic lines of rice. Phytopathology, 84:1278-1283.

Inukai, T., R.S. Zeigler, S. Sarkarung, M. Bronson, L.V. Dung, T. Kinoshita and R.J. Nelson, 1996. Development of pre-isogenic lines for rice blast-resistance by marker-aided selection from a recombinant inbred population. Theor. Appl. Genet., 93:560-567.

Jeon, J.S., D. Chen, G.H. Yi, G.L. Wang and P.C. Ronald, 2003. Genetic and physical mapping of $\mathrm{Pi5}(\mathrm{t})$, a locus associated with broadspectrum resistance to rice blast. Mol. Genet. Genomics, 269:280- 289.

Jia, Y., Z. Wang, R.G. Fjellstrom, K.A.K. Moldenhauer, M.A. Azam, J. Correll, F.N. Lee, Y. Xia and J.N. Rutger, Rice Pi-ta gene confers resistance to the major pathotypes of the rice blast fungus in the United States. Phytopathology, P-2-4-0115-02R(296-300).

Jia, Y.L., S.A. McAdams, G.T. Bryan, H.P. Hershey and B. Valent, 2000. Direct interaction of resistance gene and avirulence gene products confers rice blast resistance. EMBO J., 19:4004-4014.

Jiang, J. and S. Wang, 2002. Identification of a 118-kb DNA fragment containing the locus of blast resistance gene Pi-2(t) in rice. Mol. Genet. Genomics, 268:249-252.

Johnson, R., 1981. Durable resistance: definition of, genetic control, and attainment in plant breeding. Phytopathology, 71:567-568.

Joshi, B.K., 2004. Rice gene pool for mid and high hills and its conservation in Nepal. In: B.K. Joshi, S.L. Joshi and K.P. Paudyal (eds.). Agricultural Research for Enhancing Livelihood of Nepalese People. Proceedings of 2nd SAS-N Convention, 30 July - 1 Aug 2003, Kathmandu, pp.252-264.

Joshi, B.K., 2005. Rice gene pool for Tarai and Inner Tarai areas of Nepal. Nepal Agric. Res. J., 6:10-23.

Kaji, R., T. Ogawa and M. Nishimura, 1997. RFLP mapping of a blast resistance gene, Pit, in rice. Breed. Sci., 47 (Suppl 1):37.

Katsube, T. and Y. Koshimizu, 1970. Influence of blast disease on harvest of rice plants. 1. Effect of panicle infection on yield components and quality. Bull. Tohoku Agric. Exp. Station, 39:55-96.

Liu, B., S.H. Zhang, X.Y. Zhu, Q.Y. Yang, S.Z. Wu, M.T. Mei, R. Mauleon, J. Leach, T. Mew and $\mathrm{H}$. Leung, 2004. Candidate defense genes as predictors of quantitative blast resistance in rice. Mol. Plant Microbe Interact., 17:1146-1152.

Liu, G., G. Lu, L. Zeng and G.L. Wang, 2002. Two broad-spectrum blast resistance genes, $\mathrm{Pi9}(\mathrm{t})$ and $\mathrm{Pi2}(\mathrm{t})$ are physically linked on rice chromosome 6. Mol. Genet. Genomics, 267:472-480.

Liu, X.Q., L. Wang, S. Chen, F. Lin and Q.H. Pan, 2005. Genetic and physical mapping of $\mathrm{Pi} 36(\mathrm{t})$, a novel rice blast resistance gene located on rice chromosome 8 . Mol. Genet. Genomics, DOI 10.1007/s0048-005-0032-5

Mackill, D.J. and J.M. Bonman, 1992. Inheritance of blast resistance in near-isogenic lines of rice. Phytopathology, 82:746-749.

Manandhar, H.K., B.J. Thapa and P. Amatya, 1985. Efficacy of various fungicides on the control of rice blast disease. Journal of Institute of Agriculture and Animal Sciences, $6: 21-29$.

Manandhar, H.K., K. Shrestha and P. Amatya, 1992. Seed-borne diseases. In:S.B. Mathur, P. Amatya, K. Shrestha and H.K. Manandhar (eds,).Plant diseases, seed production and seed health testing in Nepal. Danish Government, Institute of Seed Pathology for Developing Countries, Copenhagen, Denmark, pp.59-74.

Manandhar, H.K., 1984. Seed treatment against rice leaf blast. Nepalese Journal of Agriculture, 15:189.

Manandhar, H.K., 1987. Rice diseasesin Nepal. Plant Pathology Division, Department of Agriculture/HMG, Nepal and Winrock International, USAID, 204pp. 
McCouch, S.R., G. Kochert, Z.H. Yu, Z.Y. Wang, G.S. Khush, W.R. Coffman and S.D. Tanksley, 1988. Molecular mapping of rice chromosomes. Theor. Appl. Genet., 76:815-829.

McCouch, S.R., L. Teytelman, Y.B. Xu, K.B. Lobos, K. Clare, M. Walton, B.Y. Fu, R. Maghirang, Z.K. Li, Y.Z. Xing, Q.F. Zhang, I. Kono, M. Yano, R. Fjellstrom, G. DeClerck, D. Schneider, S. Cartinhour, D. Ware and L. Stein, 2002. Development and mapping of 2240 new SSR marker for rice (Oryza sativa L). DNA Res., 9:199-207.

McCouch, S.R., R.J. Nelson, J. Tohme and R.S. Zeigler, 1994. Mapping of blast resistance genes in rice. In: R.S. Zeigler, S.A. Leong and P.S. Teng (eds.). Rice Blast Disease.CAB International in association with International Rice Research Institute, pp.167-186.

Michelmore, R.N., I. Paran and R.V. Kesseli, 1991. Identification of markers linked to disease-resistance genes by bulked segregant analysis: A rapid method to detect markers in specific genomic regions by using segregating populations. Proc. Natl. Acad. Sci., 88:9828-9832.

Nakamura, S., S. Asakawa, N. Ohmido, K. Fukui, N. Shimizu and S. Kawasaki, 1997. Construction of an $800-\mathrm{kb}$ contig in the nearcentromeric region of the rice blast resistance gene $\mathrm{Pi}$-ta2 using a highly representative rice BAC library. Mol. Genet. Genomics, 254:611-620.

Naqvi, N.I. and B.B. Chattoo, 1996. Molecular genetic analysis and sequence- characterized amplified region-assisted selection of blast resistance in rice. In: Rice Genetics III. IRRI, Manila, The Philippines, pp.570-576.

Ou, S.H., 1985. Rice Diseases. 2nd ed. Commonwealth Mycological Institute. Kew, Surrey, England, 380pp.

Pan, Q.H., L. Wang and T. Tanisaka, 1999. A new blast resistance gene identified in the Indian native rice cultivar Aus373 through allelism and linkage tests. Plant Pathol., 48:288-293.

Pan, Q.H., Z.D. Hu, T. Tanisaka and L. Wang, 2003. Fine mapping of the blast resistance gene Pi15, linked to Pii, on rice chromosome 9. Acta Bot. Sinica, 45:871-877.

Peng, S.Q., F.Y. Huang, G.C. Sun, E.M. Liu, Y.J. Sun, R.X. Ai, J.X. Zhao, S.Z. Bai and F.H. Xiao, 1996. Studies on durably resistance to blast disease in different latitudes for rice. Scientia Agricultura Sinica, 29(2):52-58.

Pradhanang, P.M., 1988. Outbreak of blast disease at Lumle Agricultural Centre (LAC) and its extension command area (ECA). In:Proceedings of the first national rice blast workshop. National Agricultural Research and Services Center, National Rice Research Program,Birganj, Nepal, pp.61-69.

Sah, D.N. and S. Malla, 2003. Resistance to blast in rice under hill conditions. In: Proc. 23rd National Summer Crops Research Workshop, 2-4 July 2002, Kathmandu, pp.254-261.

Sah, D.N., 1989. Effects of flooding and leaf wetness duration on resistance of rice lines to Pyricularia oryzae. Journal of Institute of Agriculture and Animal Sciences, 10:41-48.

Sallaud, C., M. Lorieux, E. Roumen, D. Tharreau, R. Berruyer, P. Svestasrani, O. Garsmeur, A. Ghesquiere and J.L. Notteghem, 2003. Identification of .ve new blast resistance genes in the highly blast-resistant rice variety IR64 using a QTL mapping strategy. Theor. Appl. Genet., 106:794-803.

Shi, D., S.Y. Sun and Z.T. Shen, 1989. Preliminary studies on the resistance reaction and resistance genetics of leaf blast and neck blast for various rice varieties. Acta Agriculturae Zhejiangensis, 1:94-96.

Silue, 'D., D. Tharreau and J.L. Notteghem, 1992. Identification of Magnaprothe grisea avirulence genes to seven rice cultivars. Phytopathology, 82:1462-1467.

Sirithunya, P., S. Tragoonrung, A. Vanavichit, N. Pain, C. Vongsaprom and T. Toojinda, 2002. Quantitative trait loci associated with leaf and neck blast resistance in recombinant inbred line population of rice. DNA Research, 9:79-88.

Tabien, R.E., Z. Li, A.H. Paterson, M.A. Marchetti, J.W. Stansel and S.R.M. Pinson, 2000. Mapping of four major rice blast resistance genes from 'Lemont' and 'Teqing' and evaluation of their combinatorial effect for field resistance. Theor. Appl. Genet., 101:1215-1225. 
Thapa, B.J. and H.K. Manandhar, 1985. Performance of differential, resistant gene donor and recommended rice cultivars in rice blast nursery at Khumaltar, Nepal. Nepalese Journal of Agriculture, 16:116-123.

Tsunematsu, H., M. Jeanie, T. Yanoria, L.A. Ebron, N. Hayashi, I. Ando, H. Kato, T. Imbe and G.S. Khush, 2000. Development of monogenic lines of rice for blast resistance. Breeding Sci., 50:229-234.

Upadhaya, M.P. and B.K. Joshi, 2003. Plant genetic resources in SAARC countries: Their conservation and management: Nepal chapter. SAARC Agriculture Information Center, pp.297-422.

Valent, B., 1990. Rice blast as a model system for plant pathology. Phytopathology, 80:3336.

Wang, G.L., D.J. Mackill, J.M. Bonman, S.R. McCouch, M.C. Champoux and R.J. Nelson, 1994. RFLP mapping of genes conferring complete and partial resistance to blast in a durably resistant rice cultivar. Genetics, 136:1421-1434.

Wang, Z.X., M. Yano, U. Yamanouchi, M. Iwamoto, L. Monna, H. Hayasaka, Y. Katayose and T. Sasaki, 1999. The Pib gene for rice blast resistance belongs to the nucleotide binding and leucinerice repeat class of plant disease resistance genes. Plant J., 19:55-64.

Wu, J.L., P.K. Sinha, M. Varivar, K.L. Zheng, J.E. Leach, B. Courtois and H. Leung, 2004. Association between molecular markers and blast resistance in an advanced backcross population of rice. Theor. Appl. Genet., 108:1024-1232.

Yeh, W.H. and J.M. Bonman, 1986. Assessment of partial resistance to Pyricularia oryzae in six rice cultivars. Plant Pathology, 35:319-323.

Zhuang, J.Y., W.B. Ma, J.L. Wu, R.Y. Chai, J. Lu, Y.Y. Fan, M.Z. Jin, H. Leung and K.L. Zheng, 2002. Mapping of leaf and neck blast resistance genes with resistance gene analog, RAPD and RFLP in rice. Euphytica,128:363-370. 